WORKING PAPER

DIMENSIONS OF NATIONAL CULTURE AND THE ACCOUNTING ENVIRONMENT - THE SPANISH CASE -

Oriol Amat, John Blake, Philip Wraith and Ester Oliveras 


\title{
DIMENSIONS OF NATIONAL CULTURE AND THE ACCOUNTING ENVIRONMENT - THE SPANISH CASE -
}

\begin{abstract}
Gray (1988) has put forward a hypothesis on how a national accounting environment might reflect the cultural dimensions identified by Hofstede (1980, 1983). A number of studies have tested Gray's hypothesis, including one by Pourjalali and Meek (1995) which identified a match between changes in cultural dimensions and the accounting environment in Iran following the revolution.
\end{abstract}

In this paper we replicate this work in the context of Spain following the death of Franco in 1975 and the emergence of a democratic constitution in 1978. Specifically, we:

1) Consider Gray's hypothesis built on Hofstede's cultural dimensions and review some empirical tests of the hypotheses.

2) Building on the work of Hofstede and Gray, we: put forward some hypotheses on how we would expect cultural dimensions to change in Spain with the transition to democracy.

3) Review developments in accounting in Spain following the transition to democracy, in order to identify how well these fit with our hypotheses.

Keywords: management accounting, Spain, culture

Classifications of the Journal of Economic Literature: M41 


\section{DIMENSIONS OF NATIONAL CULTURE AND THE ACCOUNTING ENVIRONMENT - THE SPANISH CASE -}

\section{Introduction}

Gray (1988) has put forward a hypothesis on how a national accounting environment might reflect the cultural dimensions identified by Hofstede (1980, 1983). A number of studies have tested Gray's hypothesis including one by Pourjalali and Meek (1995) which identified a match between changes in cultural dimensions and the accounting environment in Iran following the revolution.

In this paper we replicate this work in the context of Spain following the death of Franco in 1975 and the emergence of a democratic constitution in 1978. Specifically we:

1) Consider Gray's hypothesis built on Hofstede's cultural dimensions and review some empirical tests of the hypotheses.

2) Building on the work of Hofstede and Gray, we:

a) Put forward some hypotheses on how we would expect cultural dimensions to change in Spain with the transition to democracy.

b) Identify the changes in the Spanish financial and management accounting environment which we would expect to arise, following Gray, from there changes in cultural dimensions.

3) Review developments in accounting in Spain following the transition to democracy in order to identify how well these fit with our hypotheses.

\section{Cultural and accounting dimensions}

Hofstede $(1980 ; 1983)$ reports on an analysis of four dimensions of culture across 39 countries. He defines culture as:

'The collective programming of the mind which distinguishes the members of one human group from another' (Hofstede 1983 p. 21).

Hofstede's four dimensions of culture are: 
1) Individualism, as an opposite to collectivism. Individualism reflects the extent to which the individual expects personal freedom. It contrasts with collectivism which is defined as the acceptance of responsibility to family, tribal, or national groups.

2) Power distance. This is defined as:

'The power distance between a boss $\mathrm{B}$ and a subordinate $\mathrm{S}$ in a hierarchy is the difference between the extent to which B can determine the behaviour of $S$ and the extent to which $S$ can determine the behaviour of B' (Hofstede 1983 p 22). In a large power distance society there is acceptance of hierarchy and no call for its justification. In small power distance societies there is an aspiration for power equalisation and a demand that inequalities be justified.

3) Uncertainty avoidance. Uncertainty about the future is a basic fact of human life. High uncertainty societies reduce the impact of uncertainty by technology, rules and rituals. Low uncertainty avoidance societies are more relaxed, so that practice counts more than principles and deviance is more tolerated.

4) Masculinity, as against femininity. Masculine values emphasise values of performance and visible achievement. Feminine values incline towards a preference for quality of life, relationships, modesty and caring for the weak.

Hofstede analysed questionnaires completed by 117,000 employees of IBM across 66 countries in the late 1970's. For each dimension questions were selected as indicative of where the respondent stood on that dimension. To give two examples:

1) As an indicator of power distance, one question asked subordinates whether their bosses took decisions in an autocratic or persuasive way.

2) One question indicative of attitudes to uncertainty avoidance is the response to the proposition "Company rules should not be broken - even if the employee thinks it is in the company's best interests" (p118-119).

Table 1 shows a summary of the Hofstede rankings for 39 countries. 
Table 1. Summary of Hofstede's rankings for 39 countries

\begin{tabular}{|c|c|c|c|c|}
\hline $\begin{array}{l}\text { Summary of } \\
\text { rankings of } 39 \\
\text { countries }\end{array}$ & $\begin{array}{c}\text { Ranking for } \\
\text { power distance* }\end{array}$ & $\begin{array}{l}\text { Ranking for } \\
\text { uncertainty } \\
\text { avoidance }\end{array}$ & $\begin{array}{l}\text { Ranking for } \\
\text { individualism }\end{array}$ & $\begin{array}{l}\text { Ranking for } \\
\text { masculinity }\end{array}$ \\
\hline Argentina & $23=$ & $6=$ & $2=$ & $18=$ \\
\hline Australia & 28 & 26 & 2 & 14 \\
\hline Austria & 39 & $17=$ & 18 & 2 \\
\hline Belgium & 11 & 3 & 8 & 20 \\
\hline Brazil & 6 & $14=$ & 25 & 23 \\
\hline Canada & 26 & 30 & $4=$ & 21 \\
\hline Chile & $14=$ & $6=$ & 32 & 34 \\
\hline Columbia & 9 & 13 & 38 & $10=$ \\
\hline Denmark & 37 & 38 & 9 & 36 \\
\hline Finland & 32 & $22=$ & 17 & 35 \\
\hline France & $7=$ & $6=$ & $10=$ & $28=$ \\
\hline Germany & $29=$ & 20 & 15 & $8=$ \\
\hline Great Britain & $29=$ & $34=$ & 3 & $8=$ \\
\hline Greece & 16 & 1 & 27 & $16=$ \\
\hline Hong Kong & $7=$ & $36=$ & 31 & $16=$ \\
\hline Indian & 4 & 33 & 21 & $18=$ \\
\hline Iran & 17 & $22=$ & 24 & $28=$ \\
\hline Ireland & 35 & $34=$ & 12 & 7 \\
\hline Israel & 38 & 12 & 19 & 25 \\
\hline Italy & 22 & 16 & 7 & $4=$ \\
\hline Japan & 21 & 4 & $22=$ & 1 \\
\hline Mexico & $2=$ & 11 & 29 & 6 \\
\hline Netherlands & 27 & 25 & $4=$ & 37 \\
\hline New Zealand & 36 & $28=$ & 6 & 15 \\
\hline Norway & $33=$ & 27 & 13 & 38 \\
\hline Pakistan & 20 & $17=$ & 37 & 22 \\
\hline Peru & $12=$ & 5 & 36 & $30=$ \\
\hline Philippines & 1 & 32 & 28 & $10=$ \\
\hline Portugal & $14=$ & 2 & 30 & 33 \\
\hline Singapore & 5 & 39 & $33=$ & 24 \\
\hline South Africa & $23=$ & $28=$ & 16 & 12 \\
\hline Spain & 19 & $6=$ & 20 & $30=$ \\
\hline Sweden & $33=$ & $36=$ & $10=$ & 39 \\
\hline Switzerland & 31 & 24 & 14 & $4=$ \\
\hline Taiwan & $17=$ & 19 & 35 & $26=$ \\
\hline Thailand & $12=$ & 21 & $33=$ & 32 \\
\hline Turkey & 10 & 10 & 26 & $26=$ \\
\hline USA & 25 & 31 & 1 & 13 \\
\hline Venezuela & $2=$ & $14=$ & 39 & 3 \\
\hline
\end{tabular}


$*$ Note: The sign $=$ next to the ranking number means that more than one country can be found in the same the position.

Punnett \& Withane (1990) review the literature on Hofstede work, observing that it has been 'both highly praised and severely criticised' (p70). They conclude that further study is warranted.

While the overall thrust of Hofsteds's work is the identification of national cultural patterns as a guide to management and organisational development, he does refer to its relevance for accounting. In a discussion of uncertainty avoidance he argues that accounting is an uncertainty absorbing process, so that 'The main function of accounting information is to maintain morale in the face of uncertainty' (p117).

Gray (1988) explored the application of Hofstede's analysis to understanding national differences in accounting. This work has been developed in Radebaugh \& Gray (1997), and it is in the light of this more recent presentation that we explore Gray's propositions here.

Gray (1988) identified four accounting values:

1) Professionalism versus statutory control. This value reflects a preference for individual professional judgement and professional self regulation, as opposed to prescriptive legal requirements and statutory control.

2) Uniformity versus flexibility. This value reflects a preference for the enforcement of uniform accounting practices between companies as opposed to flexibility in accordance with the circumstances of individual companies.

3) Conservatism versus optimism. This value reflects a preference for a cautious approach to measurement, "that enables one to cope with the uncertainty of future events". It contrasts with a "more optimistic, laissez faire, risk taking approach".

4) Secrecy versus transparency. This value reflects a preference for confidentiality, so that information about the business is disclosed only to those most closely involved with management and financing. It contrasts with a more open, transparent, publicly accountable approach. 
Links between Hofstede's cultural dimensions and Gray's accounting dimensions are postulated:

1) Professionalism is firmly linked to high individualism, given the reliance on the judgement of the individual professional and the distaste for legal control, and weak uncertainly avoidance, given the acceptance of the inevitable variety in professional judgement. More tentatively, professionalism is linked to masculinity, given the concept of assertiveness, and small power distance, given the need for mutual trust.

2) Uniformity is particularly linked to strong uncertainty avoidance and low individualism. Uniformity is also lined to high power distance, where the imposition of rules is more readily accepted.

3) Conservatism is particularly linked to strong uncertainty avoidance. There is also a link to low individualism and high masculinity.

4) Secrecy is closely linked to strong uncertainty avoidance and large power distance. There is also a link to low individualism and masculinity.

Table 2 summaries the links postulated by Gray. 
Table 2 Summary of Gray's suggested links between accounting and cultural dimensions.

\begin{tabular}{|lcccc|}
\hline & High & High & High & High \\
& Professionalism & Uniformity & Conservatism & Secrecy \\
Individualism & $\underline{\text { HIGH }}$ & $\underline{\text { LOW }}$ & LOW & LOW \\
Power distance & SMALL & LARGE & N/A & LARGE \\
Uncertainty & $\underline{\text { WEAK }}$ & $\underline{\text { STRONG }}$ & $\underline{\text { STRONG }}$ & $\underline{\text { STRONG }}$ \\
Avoidance & & & & \\
Masculinity & HIGH & N/A & HIGH & LOW \\
& & & & \\
\hline
\end{tabular}

Notes

1. Particularly strong links underlined.

A number of studies have sought to test these propositions. Here we report on four recent ones, Doupnik and Salter (1995) took the four culture dimensions identified by Hofstede and took six other factors which have been widely held to explain national accounting differences, being:

1. Legal system.

2. Relationship between business enterprises and providers of capital

3. Tax Laws

4. Inflation levels

5. Levels of education.

6. Level of economic development.

They then analysed accounting practices in 50 countries, and established clusters of similar countries. The factors with the greatest explanatory power for the clusters found were: 
1. Legal system.

2. Level of inflation.

3. Uncertainty avoidance.

4. Masculinity.

5. Market capitalisation.

6. Level of economic development.

Thus this study suggests that to fully explain the individual character of a national accounting system we need to look both at the environmental factors and at the culture dimensions.

Gray \& Vint (1995) use a survey of disclosure practices in 1982/83 (see Gray, Campbell, and Shaw 1984) to assess the relative position of 27 countries on a spectrum from openness of disclosure to secrecy, with the USA as the most open and Uruguay as the most secret country in terms of accounting disclosure. They found a particularly significant relationship between both uncertainty avoidance and individualism and the degree of secrecy. They report:

"The inclusion of power distance did not significantly improve the model....... while the inclusion of masculinity made the fit worse" (p41).

Table 3 compares Gray's propositions on the cultural dimensions explaining secrecy with the findings of the Gray and Vint study. 
Table 3. Comparison of propositions in Gray 1988 and findings of Gray \& Vint 1995

\begin{tabular}{|lcc|}
\hline $\begin{array}{c}\text { Link to high secrecy } \\
\text { posited by Gray } 1988\end{array}$ & $\begin{array}{c}\text { Link to high secrecy found in } \\
\text { study by Gray \& Vint 1995 }\end{array}$ \\
Individualism & LOW & $\underline{\text { LOW }}$ \\
Power distance & $\underline{\text { LARGE }}$ & $\underline{\text { LARGE }}$ \\
Uncertainty avoidance & $\underline{\text { STRONG }}$ & STRONG? \\
Masculinity & & HIGH? \\
\hline
\end{tabular}

Notes:

1. Strong links are underlined

2. Weak link are marked by "?"

Pourjalali \& Meek (1995) explore the change in cultural values in Iran following the revolution in 1979. They argue that the four changes in cultural variables were:

1) Lower Individualism, because of the collective force of the revolution and the impact of war.

2) Larger power distance, with inflation increasing economic differentials and war leading to more hierarchical order.

3) Stronger uncertainty avoidance, in response to inflation and crisis.

4) Higher masculinity, arising from Islamization.

They then observe four trends in Iran's accounting culture following the revolution:

1) Lower professional power and more statutory control.

2) Higher uniformity.

3) Higher conservatism.

4) Higher secrecy. 
They then compare the cultural changes they identify with the change that would be expected on the basis of the propositions put forward by Gray (1988) and the observed charges. They conclude:

"In general, we have been able to provide analytical evidence consistent with Gray's cultural value theory" (p13)

Table 4 tabulates the comparison between changes in cultural and accounting values in Iran after the revolution in a way consistent with, but rather different from, Pourjalal and Meek. Two points emerge:

1) The relationships for individualism, power distance, and uncertainty avoidance are all consistent with Gray's propositions. Two of the relationships for masculinity are not, but may be explained in each case as being outweighed by the other three dimensions.

2) The observations are consistent for all the proposed relationships emphasised in Gray 1988. 
Table 4. Summary of the Iranian case as argued by Pourjalali \& Meek 1995

\begin{tabular}{|c|c|c|c|c|}
\hline & \multicolumn{4}{|c|}{ Observed change in accounting values } \\
\hline & Lower professional power & Higher uniformity & Higher conservatism & Higher secrecy \\
\hline Lower individualism & YES & YES & YES & YES \\
\hline Larger power distance & YES & YES & N/A & YES \\
\hline $\begin{array}{l}\text { Greater uncertainty } \\
\text { avoidance }\end{array}$ & YES & YES & YES & YES \\
\hline Greater masculinity & NO & N/A & YES & NO \\
\hline
\end{tabular}


Mac Arthur (1996) reports on an analysis of representations made to the IASC by 47 companies from 9 countries on E32 'Comparability of financial statements'. He puts forward a number of hypotheses on how national cultural values might impact on the position taken in there representations, drawing on the propositions put forward by Gray (1988).

He concludes:

"For cultural values, content analyses results were consistent with the power distance and individualism hypotheses but only partly supported the femininity, masculinity and uncertainty avoidance hypotheses" (p231)

Table 5 shows a summary of the four studies. Together they represent a substantial body of evidence in support both of the value of Hofstede's four cultural variables in explaining national accounting approaches and of the value of Gray's propositions on the links between cultural and accounting variables.

Table 5. Cultural variable identified as significant in explanation of accounting variations

\begin{tabular}{|c|c|c|c|c|}
\hline & Individualism & Power distance & $\begin{array}{c}\text { Uncertainty } \\
\text { avoidance }\end{array}$ & Masculinity \\
\hline Doupnik \& Salter 1995 & & & $\sqrt{ }$ & $\sqrt{ }$ \\
\hline Gray \& Vint & $\sqrt{ }$ & & $\sqrt{ }$ & \\
\hline Pourjalali \& Meek 1995 & $\sqrt{ }$ & $\sqrt{ }$ & $\sqrt{ }$ & \\
\hline Mac Arthur & $\sqrt{ }$ & $\sqrt{ }$ & & \\
\hline
\end{tabular}

Of Hofstede's four cultural dimensions we can see, from table 1, that masculinity is the one with the weakest links posited by Gray, and from table 5, that masculinity is the dimension least identified as significant in empirical tests of Gray's propositions. 


\section{Cultural Change in Spain}

Pourjalali and Meek (1995), in the study we have summarised above, make a number of suggestions for further research. Two of these are:

1) To extend the model in their paper to other countries. In this paper we apply the model to Spain following the death of Franco in 1975 and the adoption of a democratic constitution in 1978.

2) To evaluate the effects of culture change on management, as well as financial, accounting.

In a move from dictatorship to democracy we would expect the cultural changes for three of Hofstede's cultural dimension to be the converse of those postulated by Pourjalali and Meek for Iran:

1) A move to higher individualism.

2) A move to smaller power distance.

3) A move to weaker uncertainty avoidance.

Each of these is consistent both with our own observations and with the review of Spain in the post Franco era in Hooper (1995).

We have seen above Gray's hypotheses on the relationship between cultural dimensions and financial accounting dimensions.

Taking the areas where Gray postulated particularly strong links between cultural and financial accounting dimensions we can identify related management accounting dimensions as follows:

a) Professionalism versus statutory control. In management accounting we would see this manifesting itself as the emergence of technical recommendations from the accounting profession as compared to the provision of guidance on cost and management accounting by the government. Gray sees a strong link between professionalism and the cultural dimension of individualism.

b) Uniformity versus flexibility. Since management accounting practice is not subject to the same degree of regulation and policing as financial accounting, there is not an exact equivalent here. We suggest that a similar management accounting dimension would be to contrast an uninnovative management accounting culture with one where there is a high 
degree of innovation and diversity. Following Gray we would expect a link between uniformity and high power distance and conversely a link between innovation and diversity in management accounting and smaller power distance.

c) Conservatism versus optimism manifests itself in financial accounting both in choice of accounting methods and in the making of accounting estimates. In management accounting, where a basic principle in the devising of methods is to avoid both conservatism and optimism, we would only expect to see this dimension apply in the making of estimates. Gray sees a particularly strong link between conservatism, and uncertainty avoidance.

d) Secrecy versus transparency. In management accounting this dimension might be manifested by an contrast between restriction of reports on a 'need to know' basis on the one hand to an 'open book' policy where all employees have access to financial information on the offer. Gray sees links for secrecy with both strong uncertainty avoidance and large power distance.

Table 6 summaries the changes in cultural dimensions we would expect in Spain following the transition to democracy and the related predicted financial and management accounting changes.

Table 6. A summary of our predicted financial and management accounting changes for Spain

\begin{tabular}{|l|c|c|}
\hline Relevant cultural variable & $\begin{array}{c}\text { Predicted financial } \\
\text { accounting change }\end{array}$ & $\begin{array}{c}\text { Predicted management } \\
\text { accounting change }\end{array}$ \\
\hline Higher individualism & $\begin{array}{c}\text { More professionalism rather } \\
\text { than state control }\end{array}$ & $\begin{array}{c}\text { More professional rather than } \\
\text { state guidance }\end{array}$ \\
\hline Smaller power distance & More flexibility & $\begin{array}{c}\text { More diverse and innovative } \\
\text { practices }\end{array}$ \\
\hline Weaker uncertainty avoidance & Less conservatism & $\begin{array}{c}\text { More optimistic estimates } \\
\text { Weaker uncertainty avoidance } \\
\text { and smaller power distance }\end{array}$ \\
\hline
\end{tabular}




\section{Accounting developments in Spain}

If we consider the country rankings in table 1 we find that in the three key cultural dimensions Spain ranks out of 39 countries:

$\begin{array}{ll}\text { Power Distance } & 19 \\ \text { Individualism } & 20 \\ \text { Uncertainty avoidance } & 6=\end{array}$

Thus the prospect that Spain would move towards smaller power distance and greater individualism seems more likely than the prospect of Spain embracing less uncertainty avoidance. Therefore our first two postulates, which do not rely on a move to low uncertainty avoidance are more likely to be exhibited in Spain than our second two postulates.

Considering each of our predicted financial accounting charges:

1) The move away from state control to professionalism has been led by Asociación Española de Contabilidad y Administración de Empresas (AECA), founded in 1979. Members include academics, practitioners in businesses, private practice, and government, audit firms, and companies. Currently AECA has over 4000 individual and 500 corporate members. AECA committees produce recommendation in a range of areas including accounting regulation, company valuation, management accounting, and organisational issues.

Lainez (1994) pays tribute to the success of AECA in the field of accounting regulation:

"In summary, AECA has by its own efforts introduced the dynamism which accounting regulation has required here in Spain. It has achieved this, on the one hand, by promoting and directly influencing changes in legislative regulation.... On the other hand, the documents issued by AECA cover themes which have not been dealt with in the legislative regulation or, alternatively, have only been treated in an incomplete way" (p80).

To summarise, AECA has both had a strong impact on the formulation of the legal accounting plan and produces influential, albeit voluntary, recommendations on areas not covered by legislation (see Cañibano Calvo \& Mora Enguidanos 1997).

2) A particularly striking case of increased flexibility has been a break in the traditional binding link between tax and accounting rules. The old position has been summarised: 
"tax law establishes channels through which accountancy must run, so that it is fiscal data that is recorded in place of accounting data" (Cubillo 1983 p56).

By contrast, following the PGC of 1990 Labatut (1993) observes:

"the Anglo-Saxon approach of separating and considering independently accounting and tax principles is now firmly stablished" (p208)

and

"The Plan repeals all the tax based requirements which impose requirements on accountancy" p. 220).

3) Less conservatism is evidenced by a growing awareness of creative accounting in Spain. (see for example Giner 1992, Rojo 1993, Amat \& Blake 1996). It is also evidenced by the accounting policy choices companies are making, as evidenced by the survey of 150 leading Spanish companies reported in Ernst \& Young (1995). To take two examples:

a) The number of companies including interest capitalisation in fixed assets increased from 39 in 1992 to 44 in 1993.

b) The number of companies capitalising Research and Development increased from 39 in 1992 to 46 in 1993.

4) Less secrecy is evidenced by the extensive content of the new auditing and accounting legislation of 1988-1990, going far beyond the requirements of the PGC of 1993.

The PGC goes beyond the requirements of the EU directives in introducing a new spirit of substance over form into Spanish accounting; thus there is provision for capitalisation of finances leases, although this issue is not addressed in any EU requirement.

Spain has embraced the spirit as well as the letter of the EU directives, by contrast with some other countries. Consider Germany, where the preamble to legislation implementing the fourth directive refers to the 'true and fair view' requirement:

"In spite of the pretentious formulation it is supposed that for practice there will be no principle changes" (cited by Busse von Colbe, 1984, p123). 
Similarly, in the UK the government in implementing the fourth directive, declared itself:

"at pains to impose the minimum change necessary in actual accounting practice " (Mc Bennett \& Whelan, 1992,p99)

By contrast Spain has taken the opportunity of the fourth directive to make revolutionary changes in both the philosophy and content of accounting regulation. Characteristic of Spanish commitment to European accounting harmonisation is the argument put forwards by Socias Salva (1991, pp. 183-4) that the availability of the imagen fiel override in the EU means that fewer accounting options should be permitted by the EU directives, since any problem arising for a specific company can be solved by invocation of the override.

In management accounting we can identify evidence to support two of our expected changes:

a) The transfer of responsibility for the provision of guidance on management accounting from the state to the professions is even more pronounced in the case of management as compared to financial accounting. Chauveau (1995) points out that the PGC of 1990 has departed both from the PGC of 1973 and from the French PGC, in that it no longer provides a specimen chart of cost accounts although as Lizcano Alvarez (1992) points out, the old cost account chart has never been officially withdrawn. Since its application has always been voluntary, it continues to be available for companies who wish to use it, Saez Torrecilla et al (1996) report that they found $24 \%$ of companies in a survey still using the chart, but that 'this percentage is quickly diminishing' (p191). AECA's management accounting committee has issued 16 recommendations, commencing with a very general discussion of management accounting principles and now reaching the stage of issuing industry specific guidance, the most recent being on health centres.

b) Evidence that Spanish management accountants are engaging in more diverse and innovative practices can be found in a survey sponsored by AECA (AECA 1994) which found companies considering the following:

$\begin{array}{ll}\text { Just-in-time } & 53 \% \\ \text { Total Quality } & 44 \% \\ \text { Material Requirements Planning } & 41 \% \\ \text { Computer Aided Manufacturing } & 31 \% \\ \text { Flexible Manufacturing Systems } & 30 \% \\ \text { Quality Circles } & 22 \%\end{array}$




\section{Computer Aided Process Planning 21\%}

Amat (1992) explicitly links the use of more sophisticated management accounting systems in the 1980's with social and cultural changes in Spain.

Carmona Moreno and Alvarez Gil (1994) report that in a survey of manufacturing companies $63 \%$ reported major changes in their management accounting systems in response to the new business environment.

Our two other postulates for management accounting, that weaker uncertainty avoidance will lead to less conservative estimates and that a combination of weaker uncertainty avoidance and smaller power distance will lead to more access to management information within the business are more difficult to test because:

a) There is no published comprehensive survey on these issues in Spanish companies.

b) As we have observed above, Spain starts from a position of such strong uncertainty avoidance that some weakening of that position in the transition from democracy to dictatorship is still likely to leave it as, on balance, a strong factor. Four cases, three reported in Amat 1992 and one in Amat et al 1994, show a consistent pattern of the introduction and development of management accounting in Spanish companies but a mixed response from non financial managers:

1. A small company, owner managed, employed a chief accountant who introduced a budgetary system. In meetings of managers 'little attention is paid to the information submitted by the chief accountant' (Amat 1992 p7) and when he left the company 'nobody seemed to regret it'.

2. A large company expanded the Management Accounting System (MAS) in the 1980's. 'The management control department considers the results very successful' but 'the use of the information is quite limited'. (Amat 1992 p10).

3. Another large company upgraded the MAS in 1985, apparently successfully. "In general, MAS and their use are considered very satisfactory by the manager and all of them use the information provided by the controller'. (Amat 1992 p14).

4. A medium sized firm moved through three phases: 
a) $1974-1980$

b) $1980-1986$

c) 1986-present day
No MAS, only accounting for tax and external pursposes.

Gradual introduction of MAS due to efforts made by finance managers.

MAS increasing is important because of increasing complexity.

However, 'Since cost calculations and other related financial figures were poorly understood bynon-financial managers, they were considered too complex and almost irrelevant'. (Amat et al 1994 p115).

All four cases show an increasing dissemination of financial information to non - financial managers, supporting our fourth proposition that we would expect to see less secrecy in Spain. However, the negative response of non - financial managers in three of the four cases reported does raise some question as to whether sophisticated management accounting systems fit well into the Spanish culture.

\section{Conclusion}

In this paper we have taken the links between dimensions of culture as identified by Hofstede (1983) and dimensions of financial accounting as identified by Gray (1988), and have focused on the four most strongly supported links. We have then postulated four related links for dimensions of management accounting. We put forward the direction in which cultural dimensions in Spain might be expected to change in the transition from the Franco era to democracy.

Pourjalali and Meek (1995) drew conclusions consistent with Gray's theory about culture and accounting by analysing the Iranian environment before and after the 1979 revolution. They suggest a number of approaches to further research including;

1. Application of the model to other countries.

2. Evaluation of the effect of cultural changes on management accounting. 
In this paper we have taken up these two suggestions. For financial accounting we have found strong evidence to support Gray's propositions. For management accounting we have found substantial evidence to support three of the four propositions we have explored. Thus we have added to the evidence for the theory that links cultural values to accounting values.

\section{References}

AECA (1994) "Estudio sobre la implantación de la contabilidad de gestión en España" Madrid: Asociación Española de Contabilidad y Administración de Empresas.

Amat, J. (1992) "Internal control systems at Spanish companies" in Gonzalo J.A. (ed) "Accounting in Spain 1992" Madrid: Asociación Española de Contabilidad y Administración de Empresas" pp. 321-338.

Amat, J. (1992) "Management accounting systems in Spanish firms" European Accounting Review pp. 1-25.

Amat, J., Carmona, S.,\& Roberts, H. (1994) "Context and change in management accounting systems: an Spanish case Study" Management Accounting Research, 5, pp. 107-122

Amat, O. \& Blake, J. (1996) "Contabilidad Creativa" Barcelona: Ediciones Gestión 2000.

Busse von Colbe (1984) "A true and fair view: a German perspective" in Gray S.J. \& Conoenberg A. "EEC accounting harmonization: implementation and impact of the fourth directive", North Holland, pp. 121-128.

Cañibano Calvo, L. \& Mora Enguídanos, A. (1997) "La Regulación de la información contable financiera en la Unión Europea: Paises del Sur de Europa" Madrid: Instituto de Contabilidad y Auditoría de Cuentas.

Cañibano, L. (1992) "Professional Standards: AECA accounting principles" in Gonzalo J.A. ed "Accounting in Spain 1992" Madrid: Asociación Española de Contabilidad y Administración de Empresas pp. 83-99.

Carmona Moreno, S. \& Alvarez Gil, M.J. (1994) "Automatización y systemas de costes" in Amat J. \& Amat O. (eds) "La Contabilidad de Gestión Actual: Nuevos Desarollos" Madrid: Asociación Española de Contabilidad y Administración de Empresas. pp. 213-258. 
Chauveau, B. (1995) "The Spanish Plan General de Contabilidad: Agent of Development and Innovation?," European Accounting Review, 4,1, pp. 125-138.

Cubillo, C. (1983) "Contabilidad y Fiscalidad Problemas Actuales" Revista Técnica del Instituto de Censores Jurados de Cuentas de Espana, 7, p. 56.

Doupnik, T.S. \& Salter, S.B. (1995) "External environment, Culture and Accounting Practice: A Preliminary Test of A General Model of International Accounting Development" International Journal of Accounting, pp. 189-207.

Ernst \& Young (1995) "Soluciones practicas para la elaboracion de las cuentas anuales", Madrid: Cinco Dias.

Gray, S.J., Campbell, L.G., \& Shaw, J. (1984) "International Financial Reporting" New York: MacMillan.

Gray S.J. \& Vint H.M. (1995) "The impact of culture on accounting disclosures. Some international evidence "Asia Pacific Journal of Accounting, December, pp. 33-44.

Gray S.J. (1988) "Towards a theory of cultural influence on the development of accounting systems internationally"Abacus, Vol 24, No 2, pp. 1-15.

Giner, B. (1992) "La contabilidad creativa" Partida Doble, 21 March p. 4.

Hofstede, G. (1983) "Culture's Consequences" Sage.

Hofstede, G. \& Bond, M.H.(1988) "The Confucius connection: from cultural roots to economic growth "Organisational Dynamics, 16, No 4.

Hooper, G. (1995) "The New Spaniard" London: Penguin.

Labatut, G. (1993) "Problemática actual de las relaciones contabilidad - fiscalidad al cierre del ejercico 1992: diferencias permanentes y temporales por aplicación del método del efecto impositivo", Técnica Contable, March pp 199-252.

Lainez, J.A. (1994) "Accounting and Reporting in Spain", Advances in International Accounting Vol 6 pp 45-116. 
Lizcano Alvarez, J. (1992) "Cost Accounting in Spain" in Gonzalo J. A. (ed) "Accounting in Spain 1992" Madrid: Asociación Española de Contabilidad y Administración de Empresas pp 291-306.

MacArthur, J.B. (1996) "An investigation into the influence of cultural factors in the international lobbying of the International Accounting Standards Committee: The case of E32, Comparability of financial statements "International Journal of Accounting, Vol 31 No 2 pp 21323.

McBarnet, D. \& Whelan, C. (1992) "Regulating accounting limits in the law" in M Bromwich \& A Hopwood, "Accounting and the law", London: Prentice Hall, pp 99-111.

Pourjalali \& Meek G. (1995) "Accounting and Culture: The case of Iran" Research in Accounting in Emerging Economies, Vol 3, pp 3-17.

Punnett B J \& Withane S, (1990) "Hofstede's value survey module: to embrace or abandon?" Advances in International Comparative Management, Vol 5, pp69 - 89.

Saez Torrecilla, A., Fernández Fernández A., Texeira Quiros J. and Vaquera Mosquero M. (1996) "Management Accounting in Spain: Trends in Thought and Practice" in Bhimani A. "Management Accounting in Spain: Trends in Thought and Practice" in Bhimani A. "Management Accounting: European Perspectives" Oxford University Press, pp 180-198.

Socias Salvá. A. (1991) "La normalización contable en el Reino Unido, Francia, Alemania. y España", Madrid, Asociación Española de Contabilidad y Administración de Empresas. 